
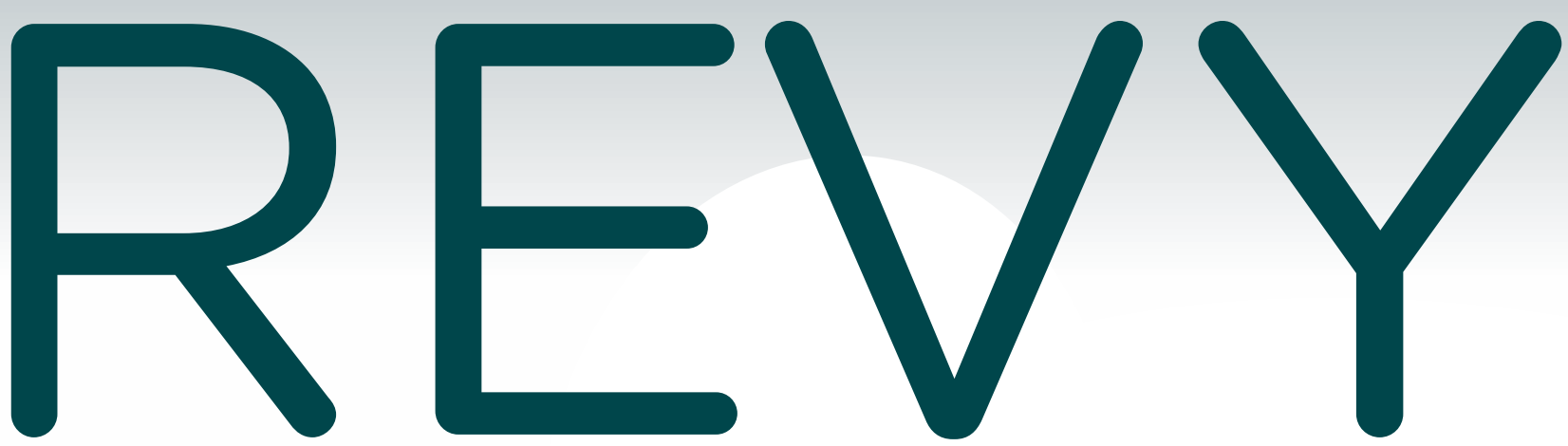

Nr. 3

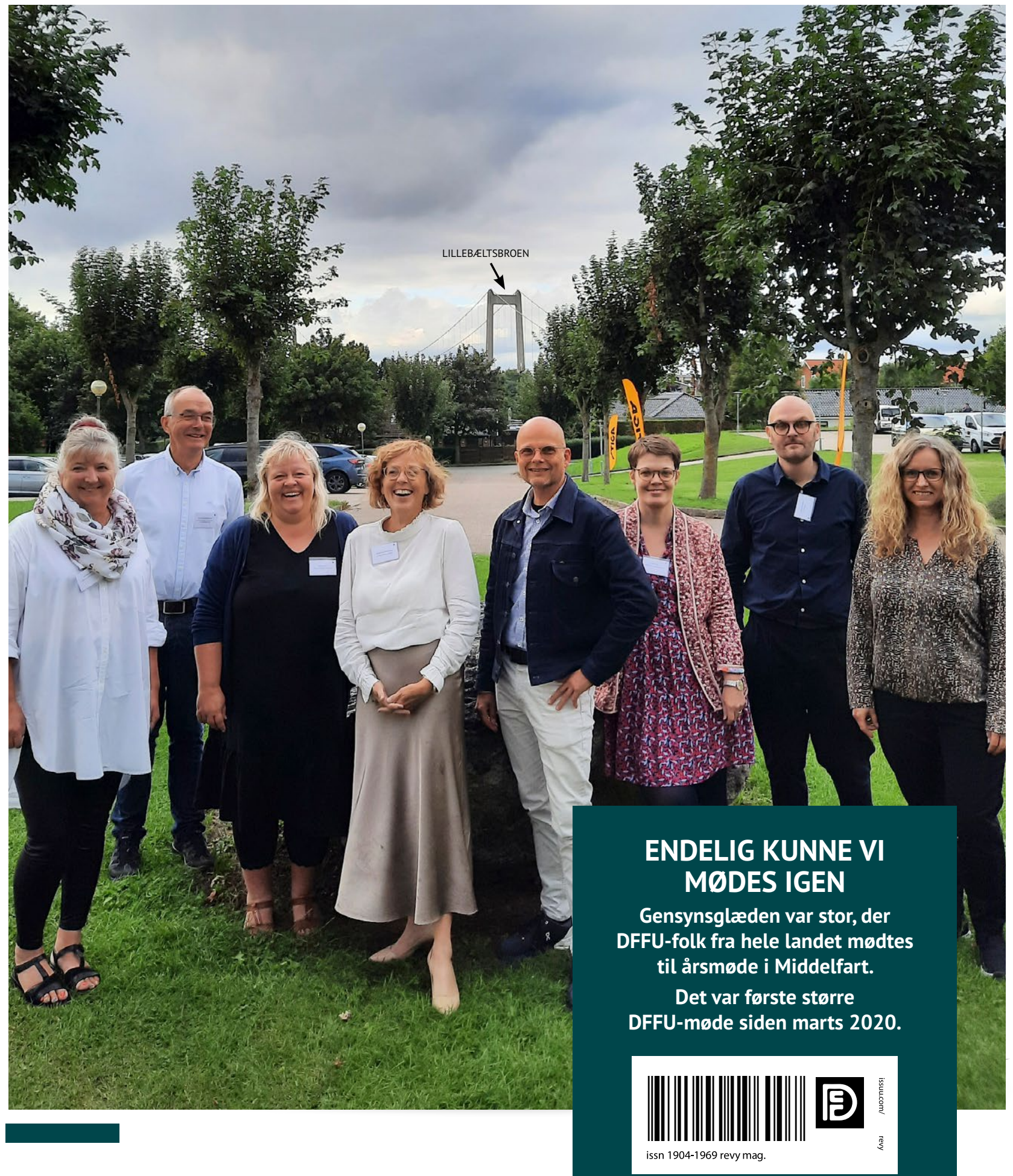


s. 3 DFFU's årsmøde i Middelfart

s. 7 \#biblioteksblik

s. 8 Tretrinsraketten og det gode samarbejde - akademiske praksisartikler

s. 11 Humaniora tilsat strøm. Digital Humanities, SDU

s. 14 RUb 50 år: På den anden planet for længe, længe siden...

s. 16 Din guide til Den Store Fusions-jungle

s. 17 RUb 50 år. "Fusion er det næste, naturlige skridt"

S. 18 RUb 50 år. Ikke sikkert, at 'one size fits all'.

s. 20 Bestyrelsen tager ordet - udflytningen af uddannelser

s. 22 DEBAT: Skrankepaver eller læringskatalysatorer?

- biblioteket som læringsmiljø

s. 24 Kunst, jeg gerne ville eje. "The Library" (Jacob Lawrence, 1960)

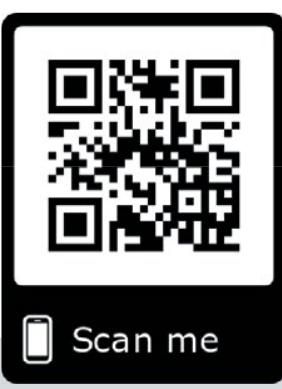

Skribenter i dette nummer

Anne-Marie Fiala Carlsen,

informationsspecialist, UCL Biblioteket

Jette Fugl, informationsspecialist, KUB Frederiksberg

Stefan Katić, redaktør REVY

Lea Lund, uddannelses- og forskningsleder,

UCL Erhvervsakademi og Professionshøjskole

Lotte Thing Rasmussen, journalist, specialkonsulent, Syddansk Universitetsbibliotek

Tina Lund, informationsspecialist, KB/KUB Frederiksberg

\section{Redaktion}

Stefan Katić (ansvarshavende)

Redaktør REVY

katic6@gmail.com, mob 50778628

\section{Redaktionsgruppen:}

Annette Refn, DTU Bibliotek

anre@dtu.dk

Mette Buje Grundsøe, AUB

mbg@aub.aau.dk

Tina Lund, KB/KUB Frederiksberg, tilu@kb.dk

\section{(på barsel) Nejra Hodzić Richter}

KUB Sdr. Campus - Det Kgl. Bibliotek neta@kb.dk

\section{Årsabonnement}

4 numre for $400 \mathrm{kr}$. plus porto

\section{Adresseændring}

Meddelelser om adresseændringer og ekspedition sendes tildffu@kb.dk

\section{Afleveringsfrister}

Nr. 4 vinter 2021 - deadline 20. oktober

Nr 1 forår 2022 - deadline 20. januar

Nr. 2 sommer 2022 - deadline 20. april

Nr. 3 efterår 2022 - deadline 20. juli

Aftalte manuskripter sendes til mail:katic6@gmail.com

\section{Annoncepriser (ex. moms)}

1 helside: $4.900 \mathrm{kr}$.

3 helsides annoncer: $10.000 \mathrm{kr}$.

Oplag: 1.000

ISSN 1904-1969

ISSN (online) 1904-1977

Årgang 43

Tryk: Kailow Graphic

Grafisk design: Designbygjedde

Forside: Årsmøde DFFU i Middelfart - den nyvalgte bestyrelse.

Foto: Stefan Katić

Følg også DFFU på Facebook: facebook.com/dfbib 


\section{Endelig kunne vi ses igen}

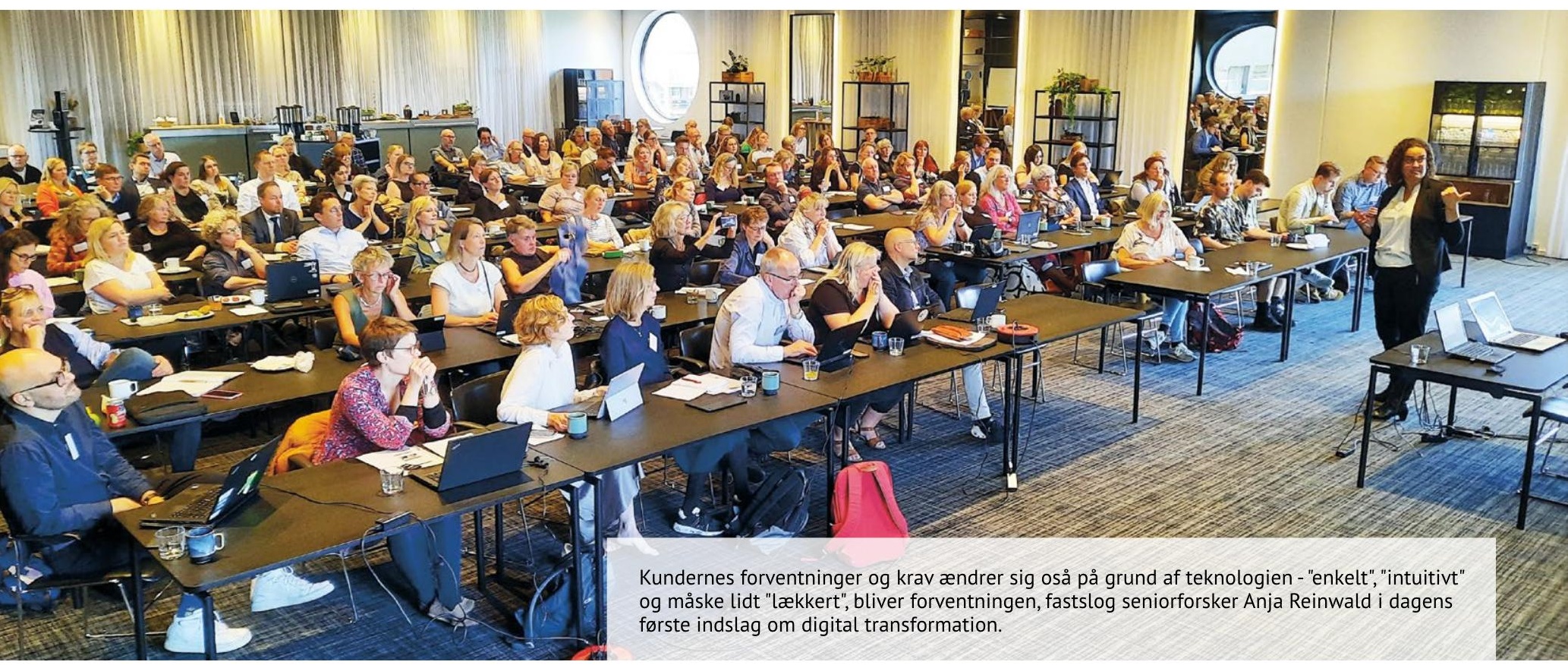

Deltagerantallet var højt og gensynsglæden stor på det første større møde i DFFU siden marts 2020.

Temaet for årsmødet, der i år fandt sted i Middelfart, var digital transformation. Og formanden så tilbage på et foreningsår i coronaens tegn.

Hvad ligner det egentlig?

Skal DFFU nu også betale nogen for at komme og gøre grin med bibliotekarer - og så tilmed under festmiddagen? Ja, det skal DFFU, hvis disse "nogen" er Specialklassen.

Fire komikere i genren impro-comedy - tre mand på scenen og én bag keyboardet. Specialklassens materiale er ganske enkelt det, publikum giver dem fra salen i den time, showet varer. Det var sjovt, rigtig sjovt. Især låneren, der var kommet hele vejen fra Holstebro for brødebetynget - men, syngende, selvfølgeligt - at aflevere en bog efter udløb af udlånstid. Men var han nu også oprettet som låner? Ind kommer institutionens it-fyren, der foreslog at "gen-star-aAAAR-te systeeee-e-emet" på bedste opera-facon.
Det var ikke bare sjovt. Det var rigtig, sjov og årsmøde-deltagerne fik grinet godt igennem til den årsmøde-middag på Hotel Comwell i Middelfart.

Men efter et corona-år, der både har været besværligt, træls, ensomt og undertiden lettere surrealistisk, trængte alle i salen vist også til at give los og igen høre latter.

Som DFFU-formand Karin Bettina Englev sagde i sin åbningstale tidligere på dagen:

- Det er første gang hele DFFU mødes siden marts 2020 .
Tekst og fotos:

Stefan Katić

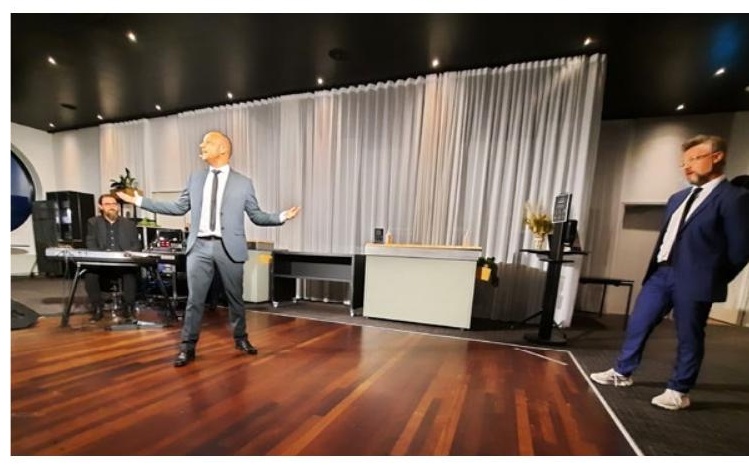

Sjovt! Impro-comedy-gruppen Specialklassen på slap line under årsmødemiddagen i Middelfart. 


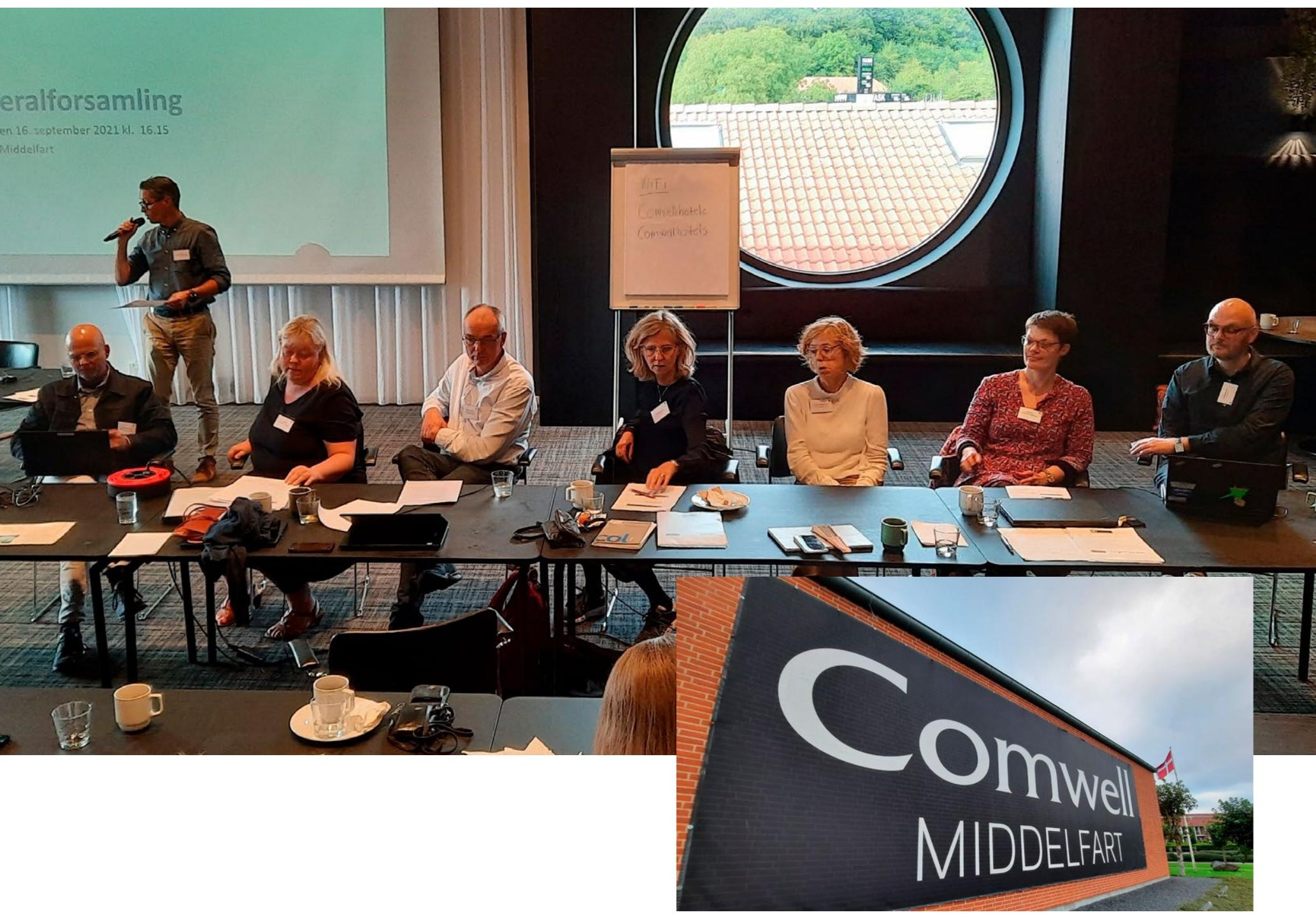

Ikke overraskende kom formandens beretning til at handle om covid-19, der med nedlukninger satte dagsorden for hele uddannelsesområdet - også bibliotekerne. Men også om medlemmerne af DFFU, der tog udfordringen op og fandt nye løsninger i den svære, mærkelige tid:

- Alle har udvist en stor velvilje og opfindsomhed for at give de studerende og forskere den bedst mulige on-

line-hjælp og assistance til at finde og bruge informationsressourcer under den fulde lukning af FFU-bibliotekerne, slog Karin Bettina Englev fast for fyldt sal med udsigt til Lillebæltsbroen og drivende september-skyer.
Fysiske arrangementer er foreningens kerneaktivitet, og de har ikke kunnet gennemføres i et corona-år. Det har kunnet mærkes på foreningens økonomi, som formanden i sin beretning betegnede som 'grundlæggende sund'.

Karin Bettina Englev adresserede også et par sager, som har eller får betydning for foreningens medlemmer.

Det ene er regeringens aftale fra juni om at udflytte af antal studiepladser på de række videregående uddannelser i Danmark (Læs også "Bestyrelsen tager ordet" side 20-21). Om FFU's rolle i dette, sagde formanden blandt andet:
- Det er vigtigt, at vi deltager i debatten, så vi sikrer os, at studerende og forskere i alle landsdele får adgang til de materialer og services, som FFU-bibliotekerne stiller til rådighed.

Også at Den Danske Forskningsdatabase uden varsel ophørte pr. januar 2021 blev noteret af formanden.

På generalforsamlingen blev det vedtaget at justere kontingentet for institutionsmedlemmer og det tildelte stemmetal, så der kommer bedre proportion mellem de to.

Den fulde beretning kan læses på $d f d f . d k$ 


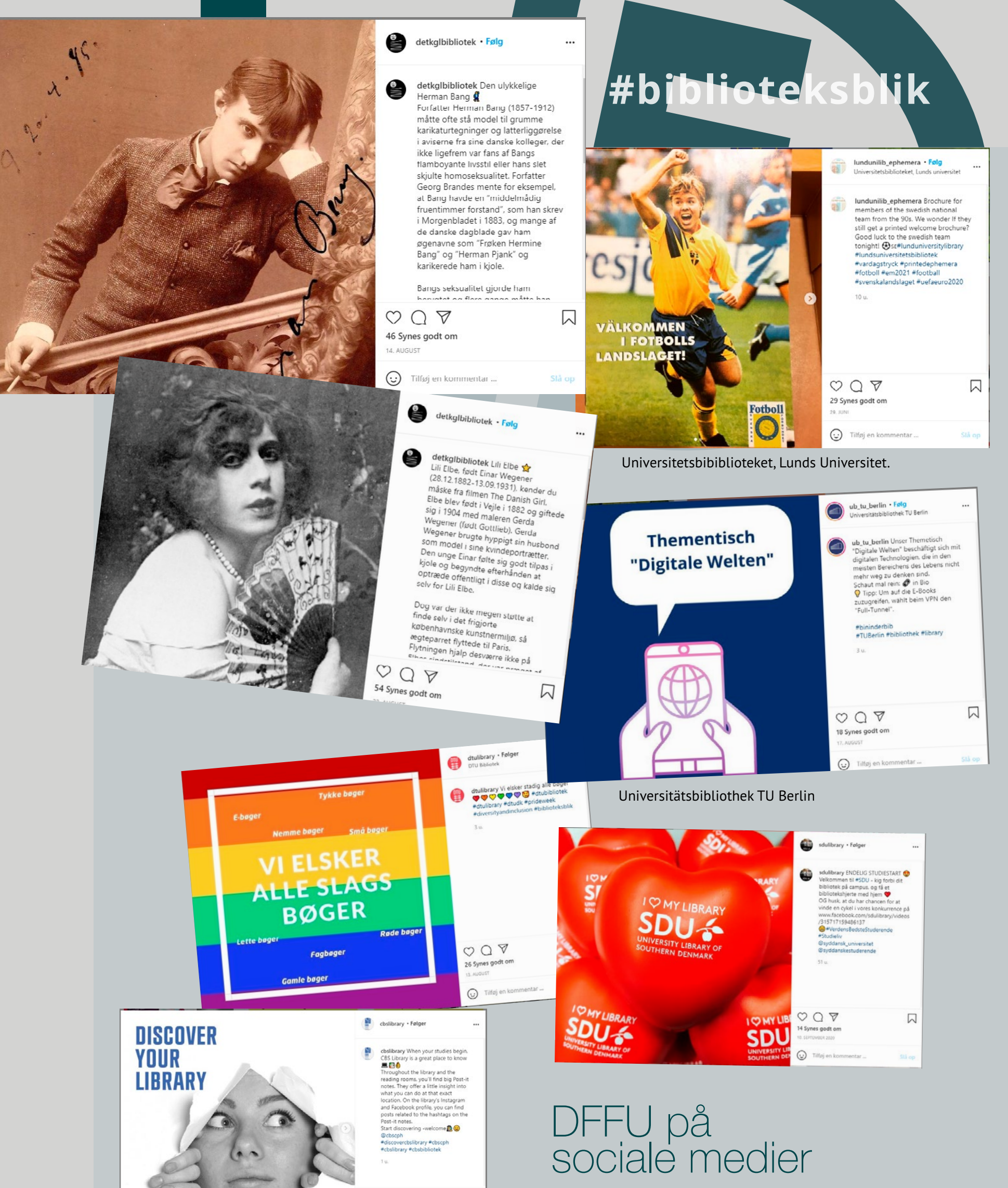


9 Der var et stort ønske om at sikre gratis adgang til artikelformatet.

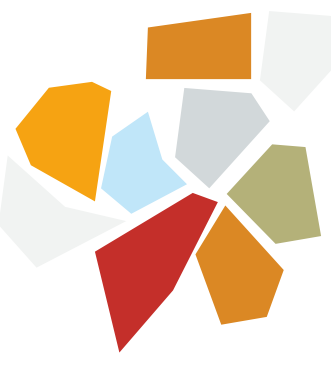

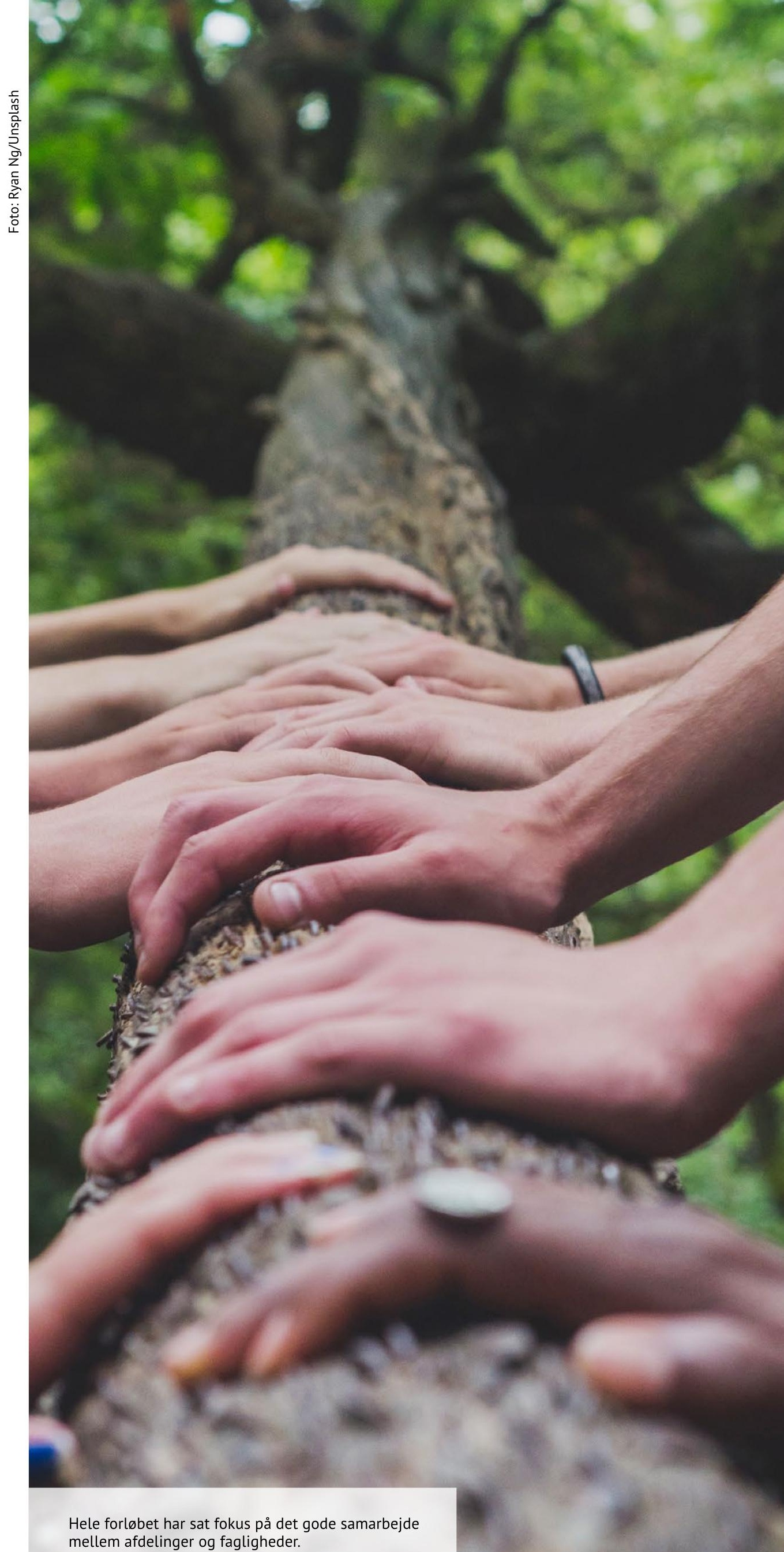




\title{
Akademiske praksisartikler
}

\section{Tretrinsraketten og det gode samarbejde}

\author{
På UCL Erhvervsakademi og Professionshøjskole \\ har vi udviklet et artikelformat til brug i professions- \\ uddannelser og efter- og videreuddannelsesaktiviteter. \\ Det er sket på tværs af afdelinger og fagligheder på UCL. \\ Formatet har fået ben at gå på, og henvender sig - på \\ tværs af organisationen - til studerende på et UC.
}

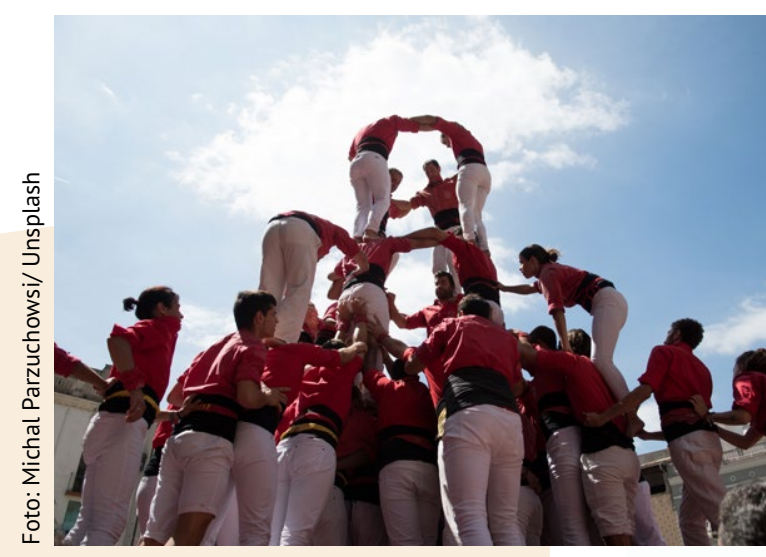

I sommeren 2019 tog Lea Lund, som dengang var ny leder på efter-og videreuddannelsesafdelingen Pædagogik \& Læring på UCL, initiativ til at udvikle et artikelformat, akademiske praksisartikler, til den professionsmålgruppe som efter- og videreuddannelsen har, inden for dagtilbud og skole. Formatet skulle være til brug som litteratur på grunduddannelser og særligt på diplom- og akademiuddannelserne.

Det skulle desuden være til brug i rekvirerede opgaver og skræddersyede forløb for skoler og organisationer, der efterspørger kompetenceudvikling for lærere og pædagogisk personale. Desuden skulle formatet kunne komme i brug i efter- og videreuddannelsens opgaveløsninger blandt andet i kommuner samt i fondsfinansierede projekter.

\section{Koblingen mellem teori og praksis}

Initiativet opstod, fordi Lea Lund blev leder for en afdeling med 25 lektorer og konsulenter som i mange år havde jongleret med undervisning af en bred målgruppe og derfor forstod både materien i selve stoffet, der skulle læres (teori) samt måden og den virkelighed, som stoffet skulle have liv i (professionens praksis). Med en mangeårig erfaring som lærebogsforfatter, redaktør og forsker på universitet udviklede Lea Lund et oplæg til et artikelformat, der kunne imødekomme koblingen mellem teori og praksis.

\section{De gode relationer}

For at sikre finansiering til projektet blev der indgået et samarbejde med en forskningsafdeling på UCL. Der blev således prioriteret forsknings- og udviklingsmidler til at udvikle formatet og til at de, der var forfattere på artiklerne, kunne honoreres for deres indsats og skiveproces.

For at sikre en levedygtighed og kvalitetsmæssig substans blev der indgået et samarbejde med UCL Biblioteket. Der var et stort ønske at sikre gratis online adgang til artikelformatet. UCL Biblioteket blev derfor kontaktet med en forespørgsel om hjælp til, hvordan det kunne sikres, at formatet kunne få ben at gå på.

\section{Den akademiske praksisartikel}

Formatet opererer ud fra en skrivetaksonomi, der følger en tretrinsraket: Et teoretisk ståsted, det vil sige en teoretisk gengivelsesdel, en case-relateret del hvor teorien/teorierne er i brug og illustreres i forhold til målgruppens praksis samt en handlingsspecifik/ praksisrelateret afslutningsdel.
At artiklerne er 'akademiske' peger på, at de henvender sig til undervisning, uddannelse og forskning ved højere læreanstalter. Pointen er, at det er et stykke 'pensumlitteratur' kva Blooms taksonomi i brugen af teori i praksis, og kan indgå som litteratur på fx pædagogiske diplomuddannelser. Det må således ikke blot være en reklame eller en gengivelse af et begreb. For at sikre dette udviklede man en systematisk ramme i form af en skrive-tretrinsraket og en forfattervejledning til formålet.

Da formatet ikke er fagfællebedømt, er der fokus på, at fagredaktøren sikrer en akademisk tilgang i forhold til, at artiklen opbygges efter Blooms taksonomi (Blooms taksonomi er en hierarkisk opstilling af kvalifikationer og kompetencer. Den beskriver, at basisviden er nødvendig, før analyse er mulig, Red.) Det er væsentligt, at redaktøren har en videnskabelig baggrund, gerne ph.d. og/eller redaktionel erfaring med akademiske udgivelser. Dette tydeliggøres i artiklens kolofon, som en blåstempling. Derudover skal det sikres, at referencer er korrekte og følger den pågældende standard. 
Derfor har samarbejdet med UCL Bibliotekets medarbejdere været givende, eftersom de bistår forfatterne i korrekt brug af referencesystemet Zotero, APA og registrering i UC Viden.

At artiklerne er 'praksisorienterede' betyder blandt andet, at de har et praksisrettet produkt til brug i den professionelles hverdag, fx ved at alle artiklerne stiller refleksionsspørgsmål til slut og indeholder øvelsesark og/eller modeller og figurer, der skal understøtte, at artiklen kan bruges i praksis.

\section{Samarbejdet}

Der blev hurtig enighed om, at artiklernes format var et vigtigt element, men også at det var nødvendigt at beskrive de elementer, der ligger uden om selve artiklen - både for at sikre kvaliteten, men også for at sikre en ensartethed $i$ produktionen. Arbejdsopgaverne blev fordelt mellem efter- og videreuddannelsesafdelingen og UCL Biblioteket, og efter de første artikler i 2020, blev der evalueret på konceptet og processen. I en biblioteksfaglig optik var det tydeligt, at forfatterne skulle understøttes $\mathrm{i}$ at bruge referencehåndteringsprogrammet, hvorfor forfatterne
At artiklerne er

'praksisorienterede'
betyder blandt
andet, at de har et
praksisrettet produkt
til brug i den
professionelles
hverdag

blev tilbudt kursus i referencebrug og der blev afholdt oplæg om Zotero for hele efter- og videreuddannelsesafdelingen.

I 2020 kom de første syv artikler og i 2021 forventes det, at der kommer cirka 15 artikler.

\section{Brug og genbrug}

På UC Viden kan man se, at artiklerne har et fint download. Artiklerne er blevet brugt til undervisning i efter-og videreuddannelsen, på diplom- og akademiuddannelserne og på kurser ude i kommunerne. Interessen for formatet og for at lave noget lignende har har været stigende i UCL, og der har været holdt interne oplæg i flere afdelinger, ligesom andre UC'er har henvendt sig for at høre mere om formatet.

Hele forløbet, fra udarbejdelse af idegrundlaget, søgning af fondsmidler og involvering af UCL Biblioteket, har sat fokus på det gode samarbejde mellem afdelinger og fagligheder. Sidst, men bestemt ikke mindst, er der udgivet mange spændende artikler, der sagtens kan læses med andre briller end lige målgruppens.

Anne-Marie Fiala Carlsen er informationsspecialist i Forskningssupport, UCL Biblioteket, UCL Erhvervsakademi og Professionshøjskole

Lea Lund er uddannelses-og forskningsleder på Læreruddannelsen Fyn, UCL

Erhvervsakademi og Professionshøjskole

Mere om akademiske praksisartikler

Artiklerne kan ses her:

https://www.ucviden.dk/da/organisations/ akademiske-praksisartikler/publications

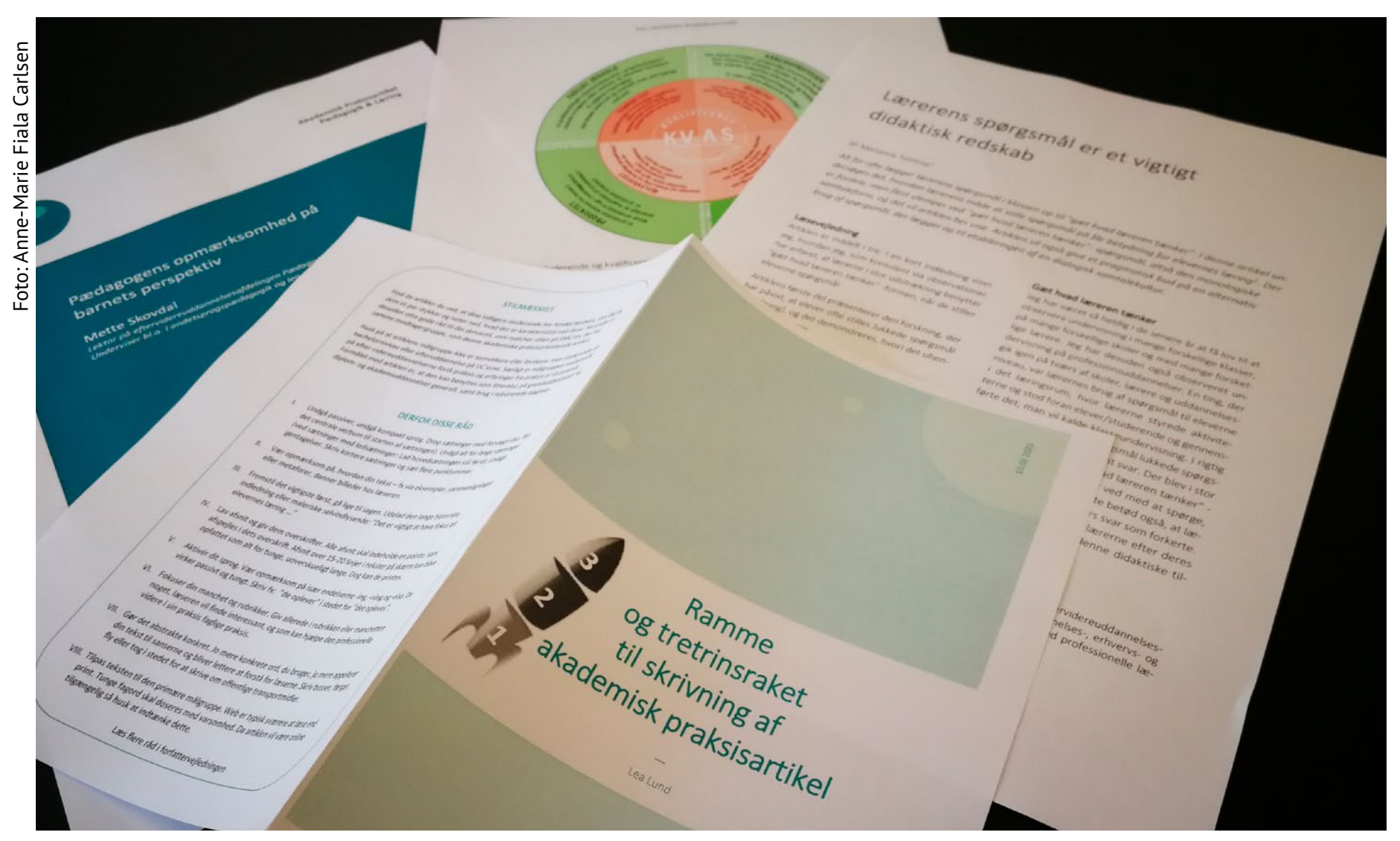

Vejledning til skrivetaksonomi for akademiske praksisartikler. 


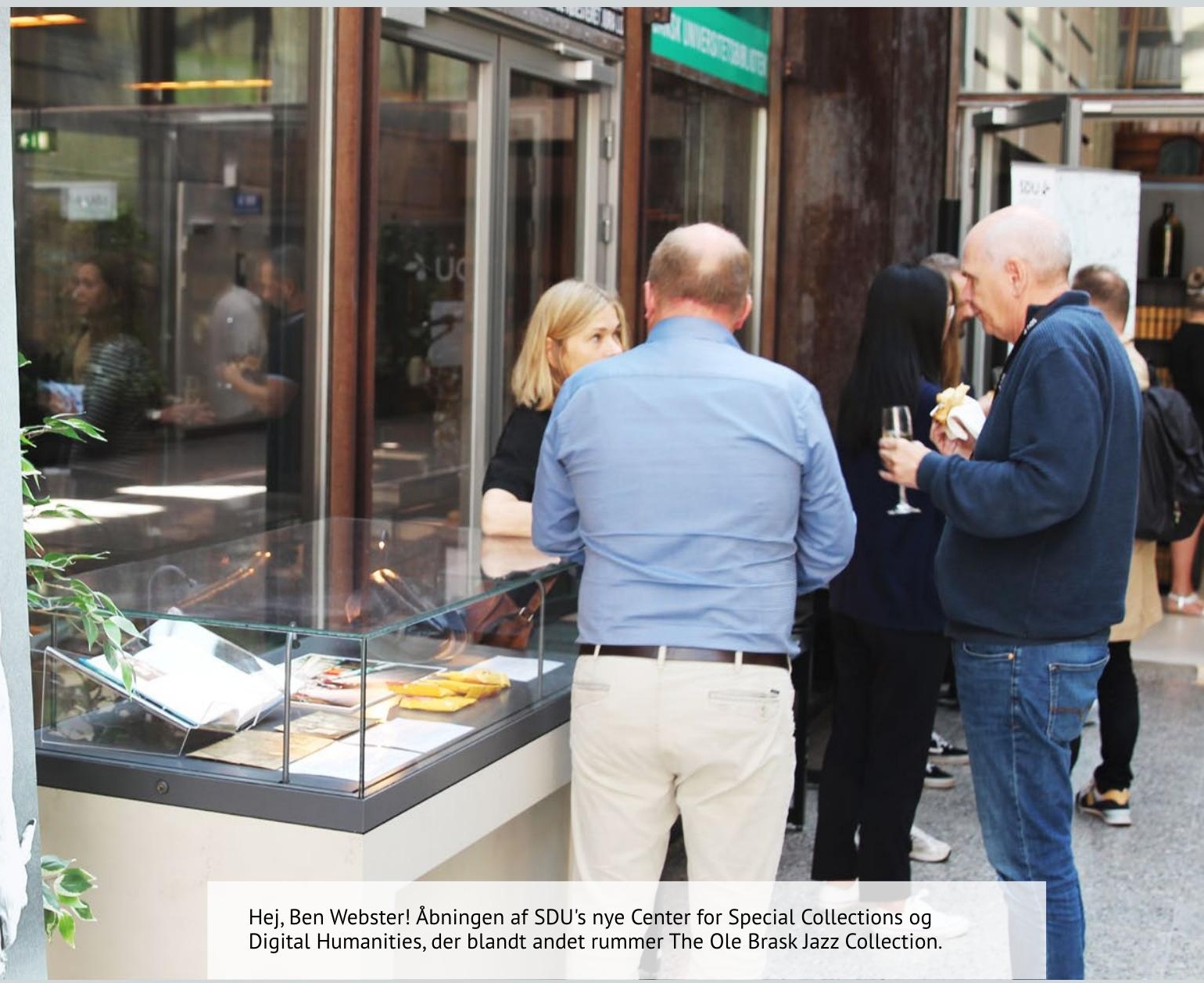

\section{Humaniora tilsat strøm}

Digital Humanities er et buzzword med stayingpower. Et nyt center på SDU forener Digital Humanities med bibliotekets mangeårige arbejde med særsamlinger.

Åbningen af det nye Center for Special Collections og Digital Humanities (SCDH) blev i starten af september fejret i centerets tilknyttede forskerlæsesal, som samtidig er nyindrettet.

Centeret samler bibliotekets arbejde med at bevare, digitalisere og formidle de mange særsamlinger, som biblioteket råder over og er et samlende punkt for arbejdet med Digital Humanities på SDU. I spidsen for centeret står Kamilla Jensen Husen, ph.d., og leder af Center for Special Collections og Digital Humanities, og hun understreger det vigtige $\mathrm{i}$ at holde centeråbningen fysisk.

- En sådan åbning er en netværksbegivenhed. Biblioteket er en naturlig medspiller for forskningsmiljøerne. Vi skal være der, hvor vores forskere er, og hvis de vil have Digital Humanities, så sørger vi for det. Vi er med til at binde alt det sammen, der foregår omkring Digital Humanities og Special Collections på SDU - vi er knuden i midten af netværket. Centeret kan understøtte både forskere og studerende i forhold til undervisning og forskning samtidig med, at vi får sat vores egne samlinger i spil, siger Kamilla Jensen Husen.

Medarbejderne på centeret har et stort netværk, som kan bruges til at sammenkæde forskellige forskere og faglige interesser.

"Vi ved, hvor der sidder nogen, der kan hjælpe. Fx kontakter H. C. Andersen Centeret os og spørger til vores udstyr. Og så sætter vi dem i forbindelse med folk fra Tek, og nu skal de scanne
Af Lotte Thing Rasmussen, journalist, specialkonsulent, Syddansk Universitetsbibliotek Fotos: Jeppe Lomholt Akselsbo 


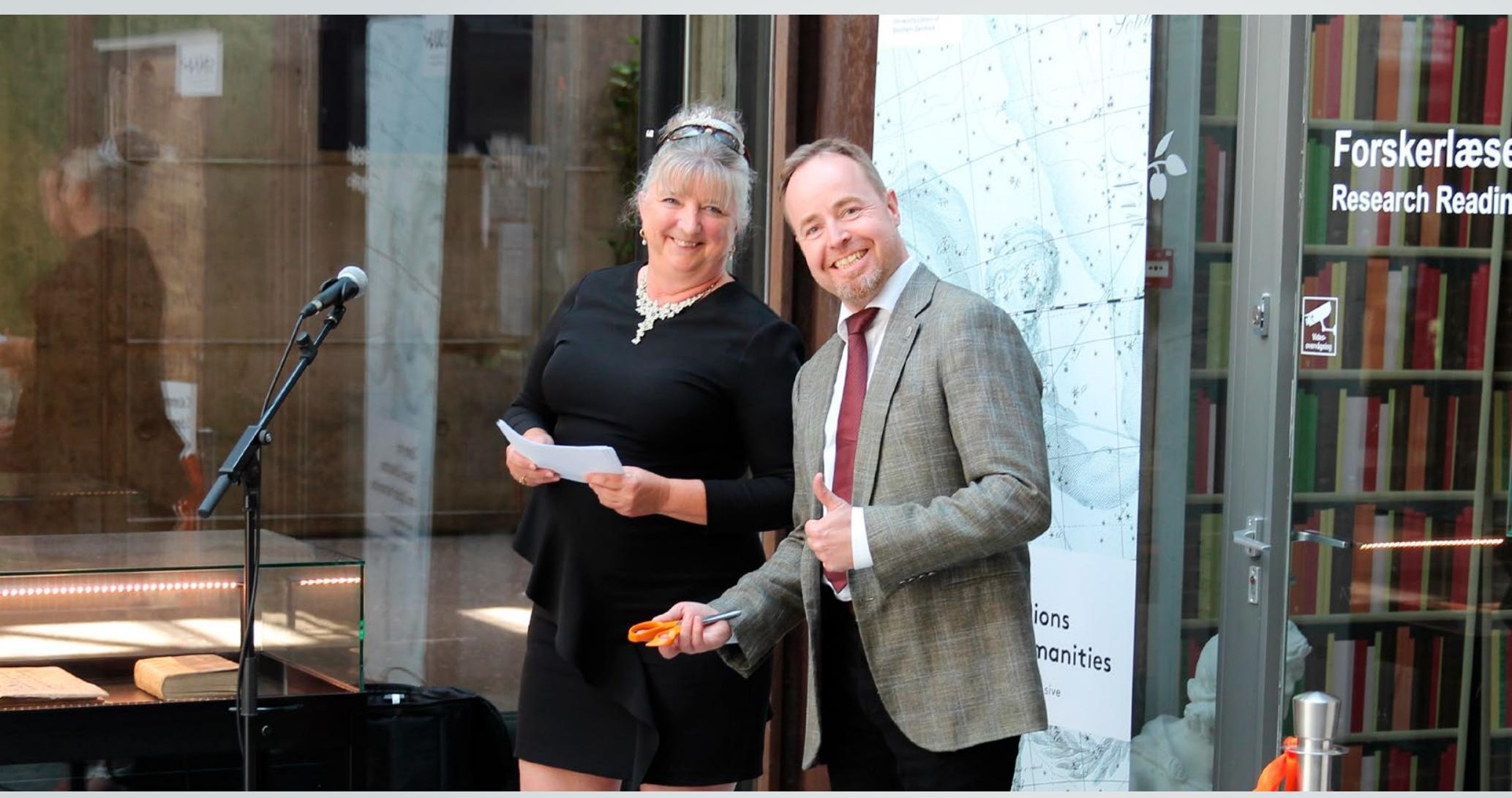

Med taler, kage og jazzmusik var den nyindrettede Forskerlæsesal rammen om åbningen af det nye Center for Special Collections og Digital Humanities. På Forskerlæsesalen er det muligt at få adgang til materiale fra særsamlingerne, de såkaldte Special Collections.

nødvendigvis en em af klassisk historie og viden. Derfor kræver det et ekstra touch at indrette. Det var Charlotte Wien, Forskningschef, Professor, Forsknings- og Analysesektionen, inde på i sin åbningstale med disse ord:

- Dels skal læsesalen være et rum til indgående studier af bibliotekets og andres skatte, dels et levende laboratorium for digitalisering og restaurering af vores kostbareste værker. Salen er, i dens kitchede fake Harry Potter med en snert af Chesterfield-stil, en slags ironisk kommentar til både "Rustenborg" (= SDU, red.) og vores topmoderne bibliotek, sagde Charlotte Wien.

Kamilla supplerer:

- Jeg synes, vi har ramt den helt rigtige atmosfære af, at her er viden til.

Efter en kort tænkepause:

- Og her kan ny viden skabes. Digital Humanities er også et kulturarvsredskab, det kan vise nye veje til kulturformidling og tilgængeliggøre materialer, der er så skrøbelige, at vi ikke kan bevare dem mere. Ting forgår.
Men det behøver de ikke. De kan gøres tilgængelige for hele verden, siger Kamilla Jensen Husen.

Og så er det tilmed et ægte verdensmål, nemlig det 11. af slagsen (Bæredygtige byer og lokalsamfund), hvor delmål 4 lyder: Bevaring og formidling af verdens kulturarv.
Ting forgår. Men det behøver de ikke. De kan gøres tilgængelige for hele verden.

Kamilla Jensen Husen

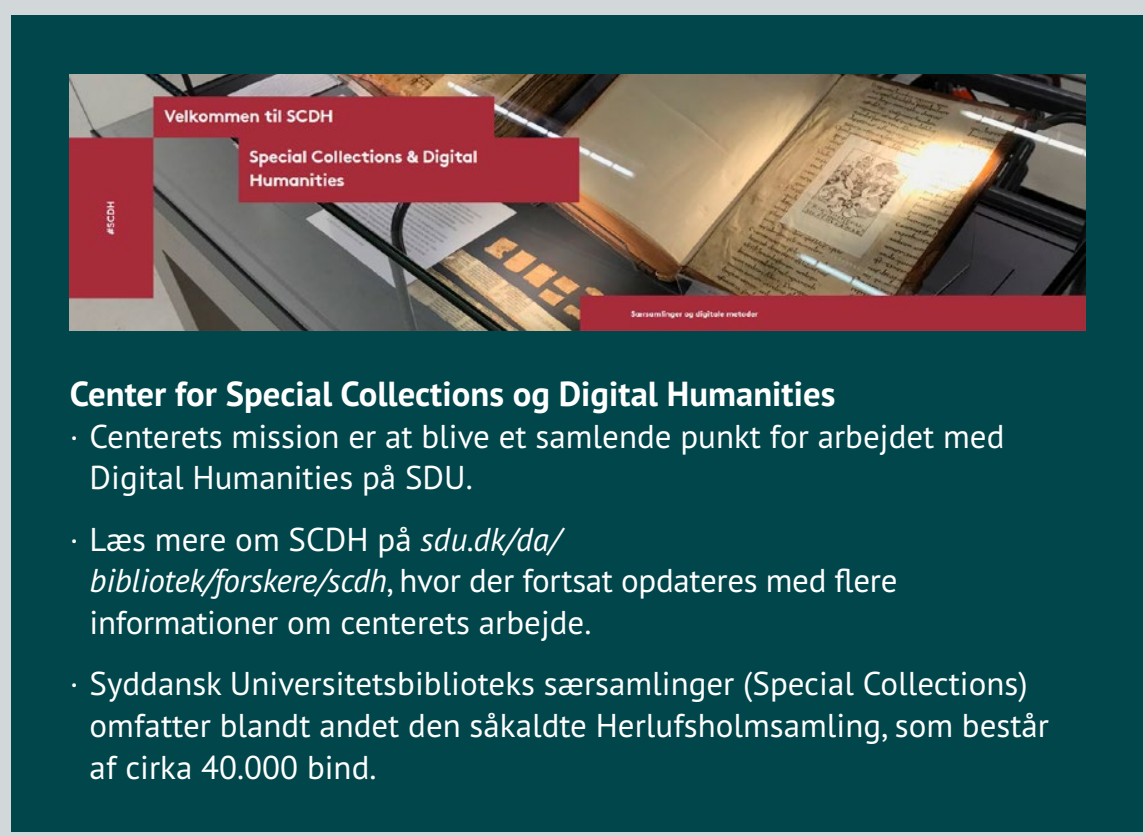




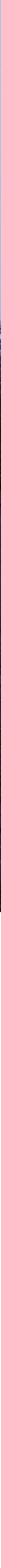




\section{På den anden planet for længe, ænge siden...}

Så fylder RUb 50 år - og bliver samtidig fusioneret med KB. So it goes.

Vil man vide noget om RUb's fødsel og første år, og samtidig blive ganske godt underholdt, så lån jubilæumsbogen "RUC i 25 år" (Roskilde Universitetsforlag, 1997) og hop frem til side 55. Her finder man den både læseværdige og underfundige artikel "Roskilde Universitetsbiblioteks tilblivelse" af Morten Laursen Vig (f. 1930), overbibliotekar på RUb 1972-86 og senere rigsbibliotekar 1986-97.

Det er en artikel på 10-11 sider, så her er der desværre kun plads til at sakse lidt indtryk fra tiden på "det røde universitet"

\section{At fungere}

"Nu var der grænser for, hvor meget man kunne lave om på et traditionelt universitetsbibliotek i 68'ernes ånd, hvis man samtidig skulle have det til at fungere. Men kunne naturligvis opbygge samlingerne, så de kunne levere den ideologiske vare, der efterspurgtes, og der måtte også tages hensyn til universitets studieformer. Men i det lange løb var det alligevel vigtigst for de fleste at have et bibliotek, som fungerede. Så vi lavede et bibliotek, som ganske meget kom til at ligne andre biblioteker."

\section{Gehør}

"Og dog var der en del, der var anderledes. Jeg havde forskellige idéer om, hvorledes et moderne universitetsbibliotek kunne indrettes, specielt i en situation uden institutbiblioteker. I Tyskland, bl.a. i Regensburg, hvor der var et relativt nyt universitet, havde man opstillet universitetsbiblioteket i "Fachbereichsbibliotheken", dvs. afdelinger, der dækkende et bestemt fagområde, på dansk "fagsale". Vi overførte ideen til RUC, og den vandt gehør."

\section{Ordbog}

"De allerførste af disse lærere var naturligvis de tre professorer i interimstyret, og her var især Niels Haastrup meget aktiv. Han er som bekendt sprogmand og lade derfor meget naturligt stor vægt på, at de nødvendige værktøjer til studiet af dansk sprog var til stede. Derfor foranledigede han, at der blev indkøbt så mange sæt af Ordbog over det danske sprog (hvert på ca. 20 bind), som vi kunne opstøve, sådan at der kunne udstationeres et sæt i alle humanistiske basishuse. De de første studenter kom, gik deres interesser i noget andre retninger, så de mange eksemplarer af ODS kom stort set kun til at samle støv, i hvert fald i hele min tid på RUC."

\section{Av-afdeling}

"Et andet træk, hvorved Roskilde Universitetsbibliotek skulle være anderledes og adskille sig fra de eksisterende universitets-og læreanstaltsbiblioteker, var etableringen af en særlig av-afdeling (av= audiovisuel, red.). Især Erling Olsen (RUC's første rektor 1972-73, udpeget 1970, red.) havde en idé om, at man i undervisningen i stort omfang skulle inddrage også de ikke-boglige medier, ikke mindst de elektroniske.
Og disse medier skulle ikke blot tjene til passiv indlæring, altså bruges på samme måde som bøgerne; de skulle også anvendes aktivt og indgå i præsentationen af projektarbejdets resultater."

\section{Integritet}

"Men samtidig sørger man for så vidt muligt at holde biblioteket fri af alle organisatoriske og styrelsesmæssige eksperimenter og at bevare en struktur, som er hensigtsmæssig i forhold til de biblioteksfaglige opgaver, der skal løses, med andre ord: sikre biblioteks integritet."

\section{Samlivsform}

"Vi fandt en samlivsform og fik i årenes løb et fortræffeligt og harmonisk samarbejde, både med RUC's politiske ledelse og med administrationen. Biblioteket forblev $\mathrm{i}$ visse henseender en slags stat i staten; det havde budgetmæssigt en betydelig selvstændighed, og undertiden opfattedes Roskilde Universitetscenter som Roskilde universitet plus Roskilde Universitetsbibliotek. Til gengæld tror jeg ikke, at jeg tager helt fejl, hvis jeg siger, at RUC fik et godt bibliotek."

"RUC i 25 år" findes elektronisk på https://forskning.ruc.dk/da/publications/ ruc-i-25-år. 


\section{Din guide til Den store fusionsjungle}

RUb fusion med KB er ikke en enlig svale. Her er nogle

af de seneste årtiers fusioneringer på FFU-området.

Som det ses af listen er der både tale om fusion af

lokaler og samlinger, andre gange af medarbejdere.

Fusioner med Det Kgl. Bibliotek (før efteråret 2017: Det Kongelige Bibliotek)

1982: Dramatisk Bibliotek bliver organisatorisk en del af Det Kongelige Bibliotek

1989: Universitetsbibliotekets 1 . afdeling bliver fusioneret med Det Kongelige Bibliotek

2005: Danmarks Natur- og Lægevidenskabelige Bibliotek (Universitetsbibliotekets 2. Afd. - UB2) Fusion

2008: Dansk Folkemindesamling fusionerer med Det Kongelige Bibliotek

2010: Danmarks Biblioteksskoles Bibliotek. Virksomhedsoverdragelse af medarbejdere: Dette bibliotek overgår til Det Informationsvidenskabelige Akademi (IVA), som bliver fusioneret ind $\mathrm{i}$ KU i 2013. Det bliver siden til Institut for Informationsstudier (INF).

2019: INF bliver fusioneret med MEF (Institut for Medier, Erkendelse og Formidling) til Institut for Kommunikation (KOMM). Bibliotekerne fusionerer ved samme lejlighed, således at biblioteket i dag hører til KOMM, hvad angår lokaler og samlinger.

2018: Medarbejderne bliver virksomhedsoverdraget til KB ligesom de øvrige institutbibliotekers medarbejdere, for hvilke det samme gælder: lokaler og samlinger er stadig på KU-hænder, altså ikke fusioneret.

Fra 2007: Danmarks Veterinær- og Jordbrugsbibliotek DVJB -> Det Biovidenskabelige Fakultetsbibliotek BVFB -> Det Natur-og Sundhedsvidenskabelige Fakultetsbibliotek, Frederiksberg Campus -> Københavns Universitetsbibliotek Frederiksberg.
2012: Danmarks Veterinær- og Jordbrugsbibliotek (KVL) Virksomhedsoverdragelse af medarbejdere.

2017: Biblioteksmedarbejderne fra det tidl. KVL bliver virksomhedsoverdraget til KB, men også her er lokaler og samlinger fortsat ejet af KU.

2016: Det Kongelige Teater indgår aftale om at overdrage hovedparten af sit arkiv til Det Kongelige Bibliotek

2017: Danmarks Kunstbibliotek Fusion, dvs. både lokaler, samlinger og medarbejdere. AEndrer navn til "Det Kgl. Bibliotek - Danmarks Kunstbibliotek".

2017: Det Administrative Bibliotek (Centraladministrationens bibliotek) Fusion

\section{7: Statsbiblioteket}

Fusion

2018: KVINFOs Bibliotek. Fusion af biblioteksdelen af KVINFO, dvs. samlinger og medarbejdere (men ikke lokaler).

2021: Roskilde Universitetsbibliotek (Rub) Virksomhedsoverdragelse af medarbejdere pr. 1. oktober.

\section{Fusioner med Aarhus University}

Library (AUL): Fra 2007: Danmarks

Veterinær- og Jordbrugsbibliotek DVJB

-> Det Biovidenskabelige Fakultetsbibliotek BVFB -> Det Natur- og Sundhedsvidenskabelige Fakultetsbibliotek, Frederiksberg Campus -> Københavns Universitetsbibliotek Frederiksberg.

- ASB Bibliotek (Handelshøjskolen

i Aarhus)

- Aarhus Tekniske Bibliotek

- Danmarks Pædagogiske Bibliotek

i 2012

- Danmarks Pædagogiske Bibliotek +

Danmarks Lærerhøjskoles Bibliotek
2017: Medarbejderne bliver virksomhedsoverdraget ligesom alle andre AUL-ansatte.

\section{DTU Bibliotek}

2013: Københavns Tekniske Bibliotek

\section{Københavns Professionshøjskoles Bibliotek}

2018: Metropol Bibliotek (sammenlagte biblioteker fra diverse uddannelsesbiblioteker)

2018: UCC Bibliotek (sammenlagte biblioteker fra diverse uddannelsesbiblioteker)

\section{Syddansk Universitetsbibliotek (SDUB)}

2006: Statens Institut for Folkesundhed (SIF) Deres bibliotek bliver nedlagt ved fusionen med SDU, da man mente at SDUB dækkede tilstrækkeligt.

\section{6: Odense Tekniske Bibliotek}

1998: Handelshøjskole Syd (Sønderborg Tekniske bibliotek var et par år (1995/96) bliveret fusioneret ind $\mathrm{i}$ HHS-biblioteket, som så bliver fusioneret med OU i 1998.

1998: SDUB bliver fusioneret med Odense Universitetsbibliotek (OU) i 1998.

\section{Professionshøjskolernes biblioteker er} bliveret fusioneret ad flere omgange, hver gang en læreruddannelse, sygeplejeuddannelse, jordemoderuddannelse, pædagoguddannelse etc. er blivet lagt ind under diverse professionshøjskoler. -sk

Listen er uden tvivl ufuldkommen og strikket sammen efter bedste evne. Stor tak til fra REVY til Hans Kristian Mikkelsen (KB), Bertil F. Dorch (SDU), Mogens Kragsig Jensen (SDU) og Claus Vesterager Pedersen (DFFU) 


\title{
Fusion er det næste, naturlige skridt
}

\author{
"Vi kan ikke løfte opgaven, hvis ikke KB er med. \\ Men selvom RUb nu fusionerer med KB, skal der \\ fortsat være plads til forskelle", siger RUb's \\ bibliotekschef Joanna Ball.
}

\section{RUb fylder 50 år her dette efterår.} Hvordan vil I fejre selve jubilæet? - Vi har ikke nogen store planer, og datoen falder sammen med vores overdragelse til KB, som vi er meget optaget af. Vi holder et lille arrangement her på biblioteket for medarbejderne. I 2022 har hele RUC jubilæum, og det er vi så med til at planlægge og fejre med dem.

\section{Hvorfor fusioneres RUb med KB?}

- RUb og KB indgik i samarbejdsaftale i 2017 for at udnytte ressourcerne bedst muligt. Det handlede mest om back end-processer, altså bibliotekssystemer, licenser etc., og er ikke så meget rettet mod front end opgaver, som betjening af studerende og forskere. Det samarbejde har været en succes, og næste skridt er så en overdragelse af medarbejdere etc. til KB pr. 1. oktober, siger Joanna Ball og tilføjer:

- I 2017 blev der ansat en KB-leder på RUb. Det var en fin løsning, men ikke holdbart. Fusionen er derfor det logiske, næste skridt, forklarer Joanna Ball.

- Biblioteket har været med til udarbejde RUC's ny ambitiøs Strategi 2030: Interconnected om banebrydende, tværfaglig forskning og problemorienteret uddannelse. Vi er kun omkring tyve medarbejdere på RUb, og hvis vi skal kunne støtte RUb's dagsordener, har vi brug for at trække på ressourcer på tværs fra KB. 20 medarbejdere betyder en vis sårbarhed i nogle områder. KB vil også kunne bidrage til vores behov for kompetenceudvikling og sikrer at vi kan være med som en del af en større faglig fællesskab, siger bibliotekschefen.

Der er blandede følelser om, at I nu er blevet en del af $K B$....?

- Det er en følsom ting, at medarbejderne skal overgå til KB.Jeg forventer dog ikke, at RUC-studerende og forskere kommer til at opleve en forandring. Der er i øvrigt ikke så mange universitetsbiblioteker tilbage, som ikke har en tilknytning til KB på en eller anden måde.

Hvad har ledelsen gjort for at medarbejdere skal være med på skiftet til $K B$ ?

- Det har været en lang og stor proces. Forud er gået en omfattende analyse med fire arbejdsgrupper, som medarbejderne har bidraget til. Et stærkt samarbejde med KB betyder at vi kan fortsat med vores god biblioteksservice, samt udvikler os i nye retninger, f.eks. Open Science.

\section{Hvilke bekymringer har} medarbejderne givet udtryk for? - Hvordan det vil påvirke deres hverdag, og nogle er bange for at blive flyttet inden for den enkelte arbejdsplads. Det er vigtigt, at der fortsat er plads til forskelle mellem de enkelte institutioner. Eksempelvis er det vigtigt, at vi kan støtte RUb's særlig uddannelsesmodel, PPL (Problemorienteret problembaseret læring) - og vi kan støtte projektgrupperne med

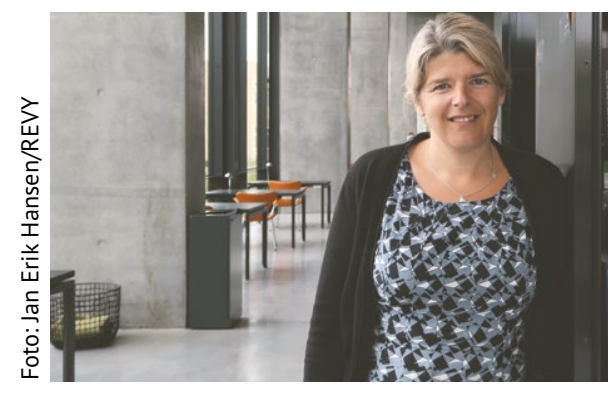

deres informationssøgning. Der er personlige, men også faglige bekymringer at vi kan fortsat være tæt på universitetet. Medarbejderne er dygtige og dedikerede, og de er optaget af at kunne give god service.

Jeg forventer ikke, at RUC-studerende og forskere kommer til at opleve en forandring.

Betyder fusionen færre eller flere ressourcer til RUb?

- Det er spørgsmål om, hvad vi ser som ressourcer. Jeg tænker "flere", for nu kan vi fylde de huller, vi har, med KB's kompetencer og kræfter, samt bidrag med vores kompetencer i andre områder på KB. Ressourcebehov ændrer sig: Vil brugerne stadig komme til bibliotekerne på samme måde? kan vi eksempelvis spørge eller vil de have øget behov for flere digital services. Jeg tror vi vil fortsat se et skift i ressourcer fra vores fysiske services til vores digitale.

Bliver det ikke et underligt jubilæum, når nu man ved at fødselaren om et øjeblik bliver 'spist' af $K B$ ?

- Det er nok mine kollegaer, du skal spørge om det. Men vi ser det som et ny kapitel i vores historie. 
ARS JUBILEUM

\section{ONE WAY $\rightarrow$}

\section{Ikke sikkert, at "one size fits all"}

- Mine kolleger er frustrerede over ikke at blive hørt om fordele og ulemper ved beslutningen.

Og over tabet af identitet, som fusionen med KB giver, siger lektor Søren Møller, der nu stopper efter 43 år med tilknytning til RUC og RUb. Men brugerne kommer antageligt ikke til at opleve nogen forandringer nu, vurderer han. 


\begin{abstract}
- Man kan sammenligne med rengøring, siger Søren Møller. Det er samme pakke, der bliver udbudt til alle. Men KB skal betjene nogle meget forskellige universiteter, og det er ikke sikkert, at one size fits all. Det er KB også selv opmærksom på, så tiden må jo vise, hvordan det kommer til at gå. Men der er stordriftsfordele, ingen tvivl om det, specielt på licensområdet, siger lektor Søren Møller, der er ansat på RUb til udgangen af oktober $\mathrm{i}$ år.
\end{abstract}

\section{Tungere beslutningsgange}

Hvorfor er du skeptisk over for

fusioneringen?

- Ulempen er, at fusioneringen kommer til at betyde større bureaukrati. Før kunne vi købe dansksproget litteratur og have det klar til udlån med få timers varsel hvis det kunne fås $i$ universitetets boglade - nu skal det igennem hele KB-møllen. Men det har vi levet med $i$ fire år siden samarbejdsaftalen med KB trådte i kraft i 2017. Dér kom ændringen. Jeg tror ikke, at der kommer store forandringer nu. Det kommer brugerne ikke til at opleve, siger Søren Møller.

- Der er nogle fordele ved at være tæt knyttet til sit universitet. Man kan hurtigere tilpasse sig universitets behov og handle hurtigere. Der bliver nogle barrierer, $\mathrm{fx}$ it-mæssige. Man bliver adskilt fra RUC og bliver en del af KB. Man forsøger at finde løsninger, men det bliver vanskeligere end det er nu, vurderer Søren Møller.
Hvad siger RUb's personale til beslutningen om at fusionere med KB? - Spørger du kollegerne, er det ingen hemmelighed, at det var en meget upopulær beslutning. Lige efter beslutningen følte de fleste frustration - og nu resignation. Det er i høj grad et spørgsmål om identitet. Det tror jeg betyder meget for mine kolleger - det gør det i al fald for mig. De skal være KB-folk nu, ikke RUC-ansatte, siger han og tilføjer:

- Derfor har jeg også selv valgt at takke nej til den ansættelsesaftale med ringere vilkår, jeg er blevet tilbudt. Jeg er ansat som lektor som den sidste af slagsen på RUb. Tidligere var vi op mod ti, der var ansat på denne måde - altså at man (som forskningsbibliotekar) har forskningstid og en relativt høj løn. Derfor er man gået væk fra denne ansættelsesform. KB har ikke villet ansætte mig i en tilsvarende stilling, så nu stopper jeg med udgangen af oktober, og bliver emeritus ved Institut for naturvidenskab og miljø på RUC, det vil sige tilknyttet ulønnet, siger han.

- Jeg har hørt forskellige reaktioner fra kollegerne, da beslutningen om virksomhedsoverdragelsen kom frem.

- Én sagde "Jeg siger op, når vi når til den dato", andre siger "Det bliver et spændende samarbejde". Men de fleste resignerer, og forsøger at få det bedst mulige ud af samarbejdet, siger den afgående RUb-medarbejder.

\section{Inddraget i den videre proces} - ikke selve beslutningen

Hvor meget er medarbejderne blevet hørt?

- Selve beslutningen om virksomhedsoverdragelsen er vi ikke blevet hørt om. En egentlig analyse af fordele og ulemper har jeg ikke set. Det har mere handlet om problemerne bagefter. Hvordan gør vi det, ikke om vi gør det.

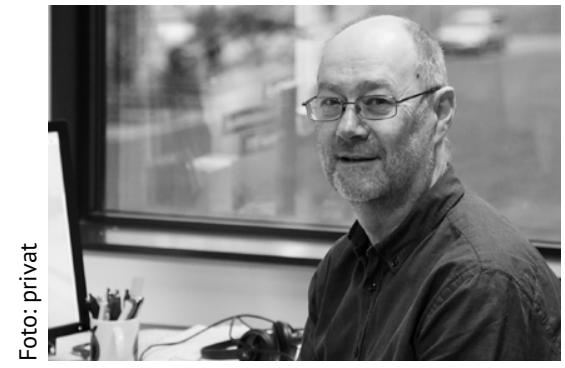

\section{BLÅ BOG}

Søren Møller er uddannet som biolog og kemiker på RUC. Han er ph.d. i kemi og har siden forsket i miljøkemi og biologi. Han har desuden publiceret om biblioteksrelevante emner.

(https://forskning.ruc.dk/da/persons/moller). 


\section{Ikke et ord om FFU'erne}

Udflytningen får også konsekvenser for FFU-bibliotekerne? Men hvilke?

Et af de emner, som har fyldt på den politiske dagsorden de sidste par måneder, og som også vil have indflydelse på FFU-bibliotekerne, er den aftale, som regeringen sammen med et bredt flertal i Folketinget har indgået om udflytning af videregående uddannelser $i$ Danmark.

Etableringen af flere uddannelser placeret uden for de store universitetsbyer vil ifølge regeringen skabe mere levende landdistrikter og gøre det mere attraktivt at bo i de mindre bysamfund. Det bagvedliggende argument er, at unge flytter på grund af uddannelsesmulighederne og efter endt uddannelse bliver i byerne frem for at flytte tilbage til de mindre byer og landdistrikter i Danmark. Dette giver blandt andet en mangel på kvalificeret arbejdskraft i visse egne. Efter mange år med centralisering af uddannelser ønskes der derfor nu en decentralisering.

Men hvad går aftalen konkret ud på? I det oprindelige udspil var der lagt op til, at universiteterne, professionshøjskolerne og erhvervsakademierne skulle nedlægge 10 procent af deres studiepladser i København, Aarhus, Odense og Aalborg eller flytte dem ud af byerne inden 2025. I den endelige aftale blev antallet af studiepladser, der skal udflyttes, dog reduceret til 5-10 procent, ligesom det ikke længere er et krav, men en målsætning frem til 2030.

\section{Ikke et ord om FFU-bibliotekerne}

Aftalen betyder, at 60 procent af uddannelsespladserne på de fire store velfærdsuddannelser (sygeplejersker, socialrådgivere, lærere og pædagoger) på sigt skal ligge uden for de største byer. Den politiske aftale omfatter desuden fem nye universitetsuddannelser: en tandlægeuddannelse i Hjørring under Aalborg Universitet, en jurauddannelse i Esbjerg under Syddansk Universitet, en lægeuddannelse i Køge under Københavns Universitet, en arkitektuddannelse i Kalundborg under Det Kongelige Akademi og en dyrlægeuddannelse i Foulum ved Viborg i regi af Aarhus Universitet og Københavns Universitet. Det hele skal finansieres blandt andet ved hjælp af en investerings- og etableringspulje og en reduktion af engelsksprogede uddannelser.

FFU-bibliotekerne er ikke nævnt i aftalen. Så hvad kommer aftalen til at betyde for FFU-bibliotekerne? Da aftalen først nyligt er indgået, er det det svært at sige konkret. Vores moderinstitutioner skal i første omgang tage stilling til, hvorvidt de vil nedlægge studiepladser i stedet for at flytte uddannelser med de logistiske og økonomiske udfordringer, det giver.

Der er ingen tvivl om, at de økonomiske udfordringer også vil få en konsekvens for FFU-bibliotekerne. Erhvervsakademierne har mange engelsksprogede studerende, og det er nok naivt at håbe, at bibliotekerne går helt fri, når der skal findes midler til etablering af nye uddannelsessteder, eller når der skal drages økonomiske konsekvenser af et faldende optag på moderinstitutionerne.

\section{Lige adgang til de materialer og services}

Samtidig er det også vigtigt, at studerende og forskere i alle landsdele har adgang til de materialer og services, som FFU-bibliotekerne stiller til rådighed. Vi er blevet rigtigt stærke som virtuelle biblioteker, men vil der ikke også være et behov for et fysisk bibliotek? Hvad betyder det for os? Skal der etableres mindre filialer med få ansatte placeret på campus, skal vi have flyvende bibliotekarer, eller skal vi indlede et samarbejde med de lokale folkebiblio-
Endnu kan vi kun gisne om, hvad aftalen konkret kommer til at betyde for FFU-bibliotekerne, men det er vigtigt, at vi deltager i debatten.

teker? Især professionshøjskolerne har allerede mindre filialer i det danske land, men konsekvensen af aftalen kan blive, at der skal etableres endnu mindre filialer.

Etableres der for eksempel en tandlægeuddannelse i Hjørring, så er Aalborg Universitet ikke tilstede med en filial $\mathrm{i}$ Hjørring i forvejen. Betyder det, at der skal etableres studiemiljø, it, bibliotek etc.? Eller kan man forestille sig et virtuelt bibliotek, hvor der er en servicetilgang generelt for alle - uanset by, størrelse eller studie?

På baggrund af de erfaringer, som vi har høstet det sidste års tid, er det i al fald nærliggende at overveje, hvorledes virtuel undervisning kan rettes mod flere geografiske lokaliteter. Det er desuden spændende, hvad aftalen kommer til at betyde for licensforhandlingerne fremadrettet.

Endnu kan vi kun gisne om, hvad aftalen konkret kommer til at betyde for FFU-bibliotekerne, men det er vigtigt, at vi deltager i debatten.
Det er nok naivt at håbe, at bibliotekerne går helt fri, når der skal findes midler til etablering af nye uddannelsessteder. 


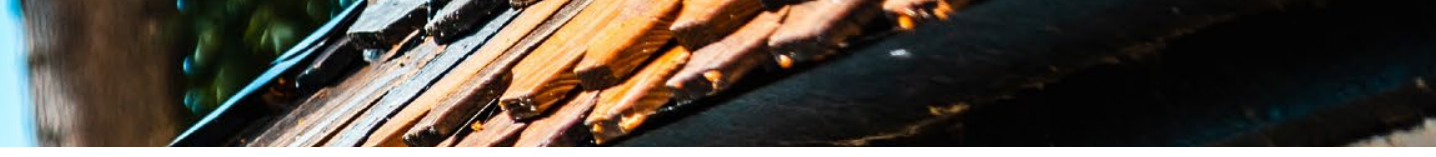

\section{BESTYRELSEN TAGER ORDET}

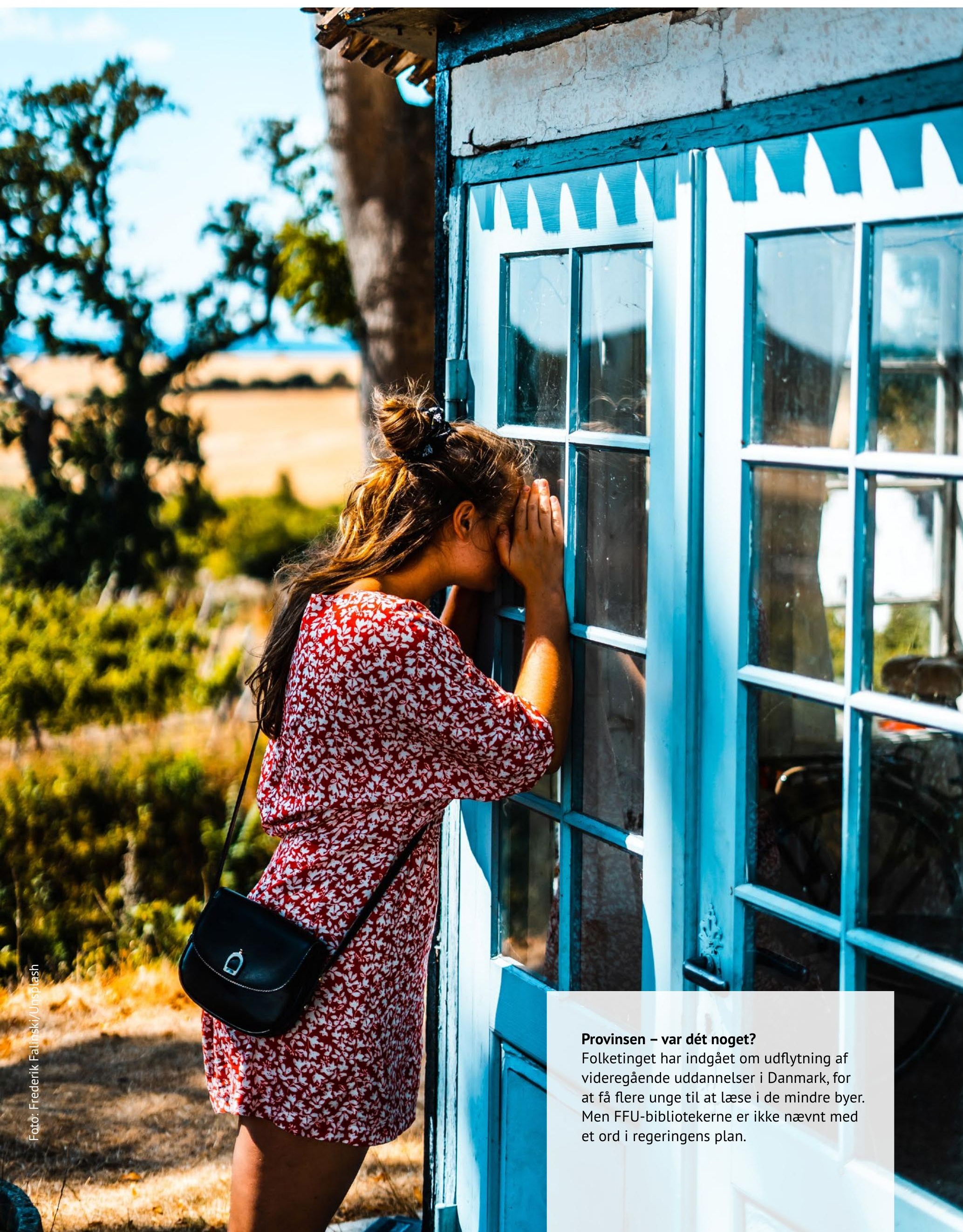




\title{
Skrankepaver eller læringskatalysatorer? - biblioteket som læringsmiljø
}

\author{
Arbejdsmiljøtilsynet løftede lige et bryn, sidst de var \\ forbi Københavns Universitetsbibliotek Frederiksberg. \\ Og med god grund. Så nu skal vores forholdsvise nye \\ informationsskranke udskiftes med en ny. Men hvilken?
}

For i kølvandet af dette genopstår samtalen, som vi kolleger, der har vagterne, har haft indbyrdes igennem flere år. Hvad er det de studerende, vores primære brugere, skal mødes med, når de går ind i biblioteksrummet, og hvordan formidler vi bedst "det" de kan få i mødet med os?

Det er jo ikke fordi, der ikke sker vejledning og undervisning i biblioteksrummet, men er alle de mange tilbud og services også synlige fra informationsskranken? For vores rolle i det fysiske biblioteksmiljø har måske ændret sig i takt med at vores brugere møder os andre steder end kun ved skranken - også i høj grad online. Men når vi møder studerende, forskere og undervisere i bibliotekets rum, så har vi jo her en oplagt mulighed for at skabe grundlag for læring og formidling - og særligt til mere grundlæggende undervisningsforløb og tilbud.

\section{Hvad siger brugerne egentlig?}

I rapporten Analyse af fremtidens behov for forskningsbiblioteksbetjening, udarbejdet for Kulturministeriet og Uddannelses- og Forskningsministeriet af analyseinstituttet Oxford Research, er der ingen slinger i valsen angående behovet og ønsket hos de studerende. Det står klart i svarene fra interviewene, som også indbefatter forskere/ undervisere og ledelsen på universiteterne.
"De studerende er også brugere af forskningsbibliotekerne. De er indskrevet på universitetet for at få en akademisk uddannelse og derved kunne mestre de faglige og videnskabelige teorier og praksisser. Forskningsbibliotekerne spiller en rolle ift. at sikre de studerendes kompetencer inden for litteratursøgning, referencehåndtering, kildekritik etc.

Samtidig har de studerende en interesse $i$, at de kan få adgang til studie-og læringsmiljøer, som i dag er en funktion, bibliotekerne ofte varetager. Samlet set har de studerende derfor en interesse $i$, at der er et bibliotek, som er integreret på deres uddannelser og er med til at skabe et levende socialt og fagligt liv på campus." (3.1.1.3 De studerende, s. 16-17)

Når rapporten beskriver (s. 27), at universitetets forskere/undervisere og studerende alle udtrykker et fremtidig behov for adgang til fysiske rum og faciliteter på biblioteket i form af et studie- og læringsmiljø, så kan vi vel godt konkludere, at vi har et uudnyttet coaching-, lærings-, undervisnings-, vejlednings- og formidlingspotentiale.

Vi kan nikke genkendende til, at vi i de senere år har haft fokus på at skabe et godt studiemiljø, men hvad med læringsmiljøet? For her har vi ikke rigtig knækket koden, som der er gjort ift. studiemiljøet, som nu giver adgang til forskellige læsepladser, stillezoner og rum til gruppearbejde, hvor det er muligt.

\section{Fra læringsvision til håndgribelig realitet}

Men hvordan griber vi læringsmiljøet og dets potentialer an? Hvordan kan vi fagligt understøtte videndeling og samarbejde og indfri behovet for et aktivt læringsmiljø? (3.2.4.1. s. 27)

"Universitetsledelsen giver i interviewene udtryk for, at de har fokus på at styrke de studerendes muligheder for adgang til fysiske rum og faciliteter, fordi det kan understøtte en højere kvalitet i uddannelserne og forskningen. Bl.a. har man på flere universiteter et strategisk mål om at skabe mere kreative læringsmiljøer, hvor det vægtes højt, at de studerendes engagement og deltagelse præger og bidrager til forskningen. Dette kan være en målsætning, hvor biblioteksrummene kan spille en rolle og fremme samarbejdet mellem forskere og studerende." (3.2.4 Behovet for biblioteksfaciliteter of studie- og læringsmiljøer, s. 27)

Der er altså en klar og udtalt forventning til, at bibliotekerne løfter opgaven eller i det mindste er med til det.

Så der hvor informationsskranken tidligere var samlings-og udgangspunkt for vores betjening, der er hele biblioteksrummet nu i spil. Her vil det være helt oplagt, at alle bibliotekets funktioner - forskerservice, undervisning, kommunikation og brugerbetjening - nu indlejres og sammen er med til at skabe læringsrummet. For som rapporten også beskriver, så er der to slags læring: Den biblioteksfaglige læring vi giver de studerende og den læring de selv skaber uden for vores "domæne", men som vi stiller rammer til rådighed for.

Måske skal vi først og fremmest blive bedre til at definere, hvad et læringsmiljø er i bibliotekssammenhænge? Hvordan kan det tage sig ud, og hvordan skal det spille sammen med det 
øvrige studiemiljø? På Københavns Universitetsbibliotek er der stort potentiale for udvikling af dette i samspil med forskelligartede studiemiljøer.

Et aktuelt eksempel er et fleksibelt læringsrum, der ønskes indrettet på KUB NORD, og hvor de første snakke om ønsker og behov er i gang, netop med input fra undervisere, datalab-folk og andre involveret i studiemiljøet. Læringsrummene skal kunne rumme en lang række funktioner, der både rummer vores tilbud og de studerendes egne muligheder for at skabe læring.

\section{Kommunikation skal tænkes ind for at nå ud}

Formidlingen af læringsrum og vores services er en anden kode, som det er interessant og nødvendigt at knække for at skabe en bevidsthed hos brugerne om mulighederne i mødet med os. Hvordan skaber vi en rød tråd gennem bibliotekets forskellige rum og vores tilbud? Og hvordan når vi ud med det, i øjenhøjde, med de studerende? Her ligger et kæmpe potentiale i forhold til, hvordan vi bruger fortællingen om læringsmiljø, ikke blot fysisk i biblioteket, men også på de sociale medier, og sætter ansigt på os selv som katalysatorer i de studerendes læring.

Vi håber, at vi har stillet mange spørgsmål til videre debat for vi ser det som et område, hvor der ligger et stort uudnyttet potentiale for FFU-bibliotekerne og som har mange afstikkere ud i alle kroge af et bibliotekets medarbejdergrupper. Vi er spændte på at følge, hvordan opgaverne løftes hos os selv, på KUB NORD og andre steder - og ikke mindst at få læringsmiljø-koden knækket. Så må vi se, om og hvordan vi bedst skriver skranken ind $\mathrm{i}$ den kode.

Rapporten Analyse af fremtidens behov for forskningsbiblioteksbetjening finder du her: https://oxfordresearch.dk/ publications/analyse-af-det-fremtidigebehov-for-forskningsbiblioteksbetjening/

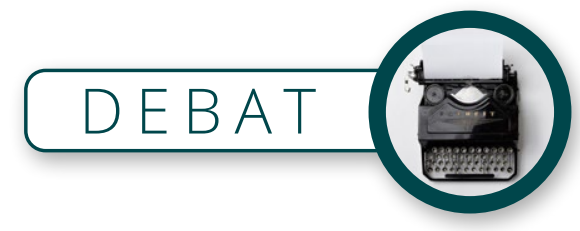

Måske skal vi først og fremmest

blive bedre til at definere,

hvad et læringsmiljø er

i bibliotekssammenhænge?

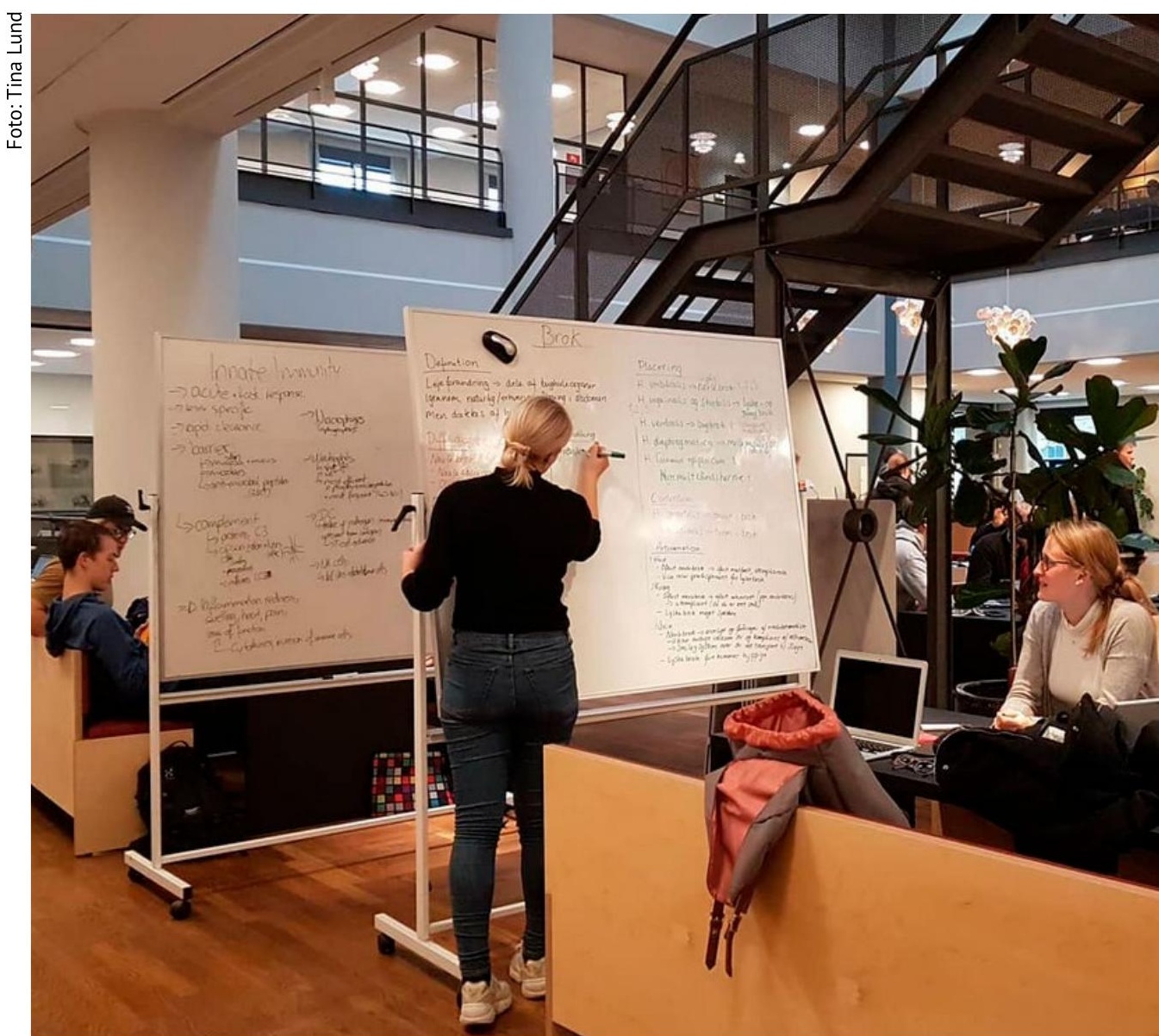

Studerende arbejder i biblioteksrummet - det er her, man

skal møde brugerne.
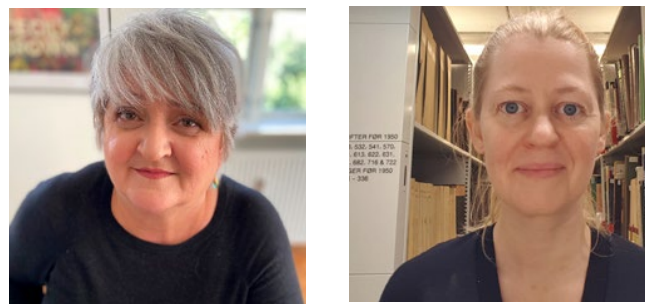

Jette Fugl og Tina Lund er begge informationsspecialister ved Københavns Universitetsbibliotek, KUB SUND/SCIENCE. 
